\title{
Genetic variability in geographical populations of Aedes aegypti (Diptera, Culicidae) in Brazil elucidated by molecular markers
}

\author{
Karina dos Santos Paduan ${ }^{1}$, João P. Araújo-Júnior ${ }^{2}$ and Paulo E.M. Ribolla ${ }^{1}$ \\ ${ }^{1}$ UNESP, Universidade Estadual Paulista, Instituto de Biociências, Departamento de Parasitologia, \\ Botucatu, SP, Brazil. \\ ${ }^{2}$ UNESP, Universidade Estadual Paulista, Instituto de Biociências, Departamento de Microbiologia \\ e Imunonologia, Botucatu, SP, Brazil.
}

\begin{abstract}
The tropical mosquito, Aedes aegypti is the most important domestic vector of urban yellow fever and dengue. Genetic population studies on this vector are important because they may lead to new tools for surveillance. An analysis of genetic structure was conducted among populations of $A$. aegypti from 11 localities in four demographic regions within six Brazilian federal states. Markers included 21 random amplified polymorphic DNA (RAPD) loci. RAPD markers were detected among populations and cluster analysis revealed two main groups. We found high genetic polymorphism $\left(\mathrm{H}_{\mathrm{s}}=0.224\right)$ and high levels of genetic differentiation between populations from different states $\left(G_{\mathrm{ST}}=0.430\right)$, as well as in populations from cities in the same state $\left(\mathrm{G}_{\mathrm{ST}}=0.410\right)$. These results indicate significant differentiation in $A$. aegypti populations in Brazil. Regression analyses of geographic distances and pairwise $F_{S T}$ values estimated from RAPD markers showed that there is a correlation between genetic structure and geographic localization.
\end{abstract}

Key words: Aedes aegypti, population genetics, random amplified polymorphic DNA, genetic variability.

Received: May 2, 2005; Accepted: October 24, 2005.

Dengue is an important viral disease transmitted to humans by arthropod vectors. Yearly, an estimated 50-100 million cases of dengue fever (DF) and 250.000-500.000 cases of dengue hemorrhagic fever (DHF) occur worldwide (Gubler, 2002). Four sorotypes of dengue viruses, DEN $1-4$, are commonly maintained in urban transmission cycles by Aedes aegypti. The primary vector of dengue has a global distribution in tropical and subtropical areas, and exhibits a distinct preference for urban areas.

In the 1940s the Pan American Health Organization (PAHO) initiated an A. aegypti eradication program in order to eliminate the vector in the Americas. This program eliminated the mosquito from 19 countries, including Brazil (Schleissman and Calheiros, 1974). Unfortunately, eradication was difficult to sustain, and by the 1970s reinvasion by this mosquito was frequent. The expansion continued during the 1980s and 1990s (Gubler, 2002). In Brazil, dengue cases represent $80 \%$ of all cases occurring in the Americas (Schatzmayr, 2000). In 2002, 794.219 dengue cases were registered, with 2.714 cases of the severe

Send correspondence to Paulo E.M. Ribolla. UNESP, Universidade Estadual Paulista, Campus de Rubião Junior, Instituto de Biociências, Departamento de Parasitologia, Caixa Postal 510, 18618000, Botucatu, SP, Brazil. E-mail: pribolla@ ibb.unesp.br. form of the disease (HF), which caused 150 deaths (FUNASA 2003).

Overall, mosquito-borne diseases have re-emerged as a significant human health problem due to a number of factors, including the lack of progress in vaccine development, the emergence of drug resistence in pathogens and inseticide resistence in mosquitoes, and the decline in socioeconomic conditions in many countries that limit disease monitoring and mosquito control efforts (Gubler 1998). Mosquito control remains the only viable strategy for preventing dengue and other mosquito borne-disease.

At present, mosquito populations are being investigated at the molecular and behavioral levels, with the goal of developing innovative control strategies. A. aegypti has been the subject of numerous studies conducted in laboratories throughout the world. Extensive DNA-based genetic studies have been made using RAPD (Random amplified polymorphic DNA) markers and this technology has been used to study a variety of characteristics in A. aegypti populations around the world, including genetic mapping and strain identification (Clark and Lanigan, 1993), the number of families at ovoposition sites (Apostol et al., 1994) and the differentiation of related species (Ballinger-Crabtree $e t$ 
al., 1992). Research regarding vector population genetics can provide new tools to improve vector surveillance elucidating genetic traits of mosquito populations that could be related to vector capacity and/or inseticide resistance.

Recently in Brazil, RAPD markers were used to demonstrate the existence of high levels of genetic differentiation of $A$. aegypti at both macro and micro-geographic levels (Ayres et al.,. 2003). In the present study, the genetic diversity in 11 Brazilian populations of $A$. aegypti representing some important commercial routes, in four demographic regions within six states were examined using RAPD. The major objectives were to obtain data on their genetic structure that may contribute to improving vector surveillance.

A total of 12 populations was analyzed. The collection sites are listed in Table 1, and the geographic locations of all sampling sites are shown in Figure 1. Samples were obtained from 11 cities distributed in the Brazilian states of Alagoas, Ceará, Mato Grosso do Sul, Paraná, Rondônia and São Paulo, from January to March in 2002. In Porto Velho, we performed 2 collections at different times (2001 and 2002). Rockefeller is a laboratory strain originally from Puerto Rico that has been reared for at least 25 years. Eggs were collected at different sites by ovitraps (usually 500 1000 ovitraps/city) and transported to the laboratory. Eggs from all positive ovitraps were pooled together and a random sample was used in this work in order to minimize relationship between mosquitoes. Mosquitoes were reared until adult stage under standard conditions (temperature 27 to $29^{\circ} \mathrm{C}$, relative humidity 80 to $90 \%$ and 12 -h light/dark cycle). Pupae were isolated and emerging virgin females were used for analysis.

DNA was extracted from each individual in lysis buffer (Tris- $\mathrm{HCl} 10 \mathrm{mM} \mathrm{pH} 8.0$ containing $\mathrm{NaCl} 0.2 \mathrm{M}$, EDTA $25 \mathrm{mM}$, sodium dodecyl sulfate $0.5 \%$ ) by ethanol

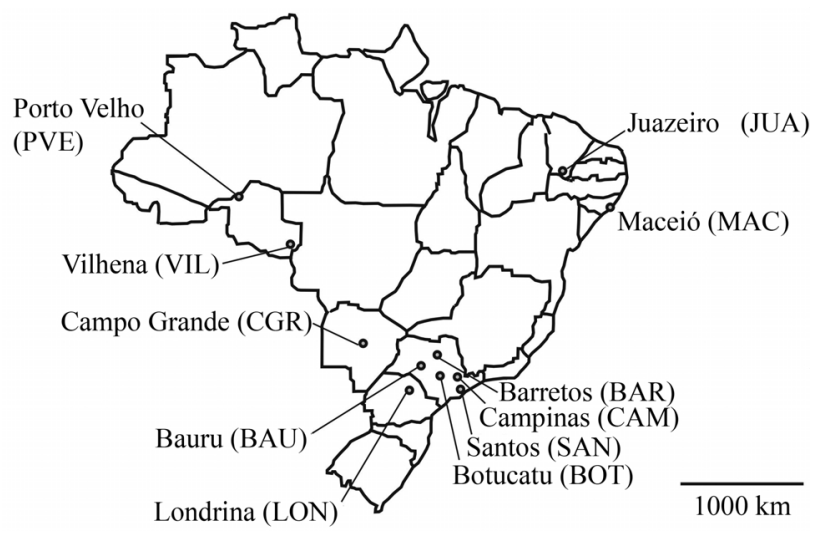

Figure 1 - Map of Brazil showing the A. aegypti collections sites.

precipitation following a modification of the procedure of Bender et al. (1983). The final DNA pellet was reconstituted in $100 \mu \mathrm{L}$ TE buffer (Tris-HCl $10 \mathrm{mM} \mathrm{pH} 8.0,1 \mathrm{mM}$ EDTA). DNA concentrations were estimated by comparison with known amounts of electrophoretic standards (Hind III digested). DNA working solutions were prepared at a concentration of $10 \mathrm{ng} / \mu \mathrm{L}$ in TE buffer and stored at $-70{ }^{\circ} \mathrm{C}$.

Each amplification was performed in a total of $25 \mu \mathrm{L}$ of reaction mixture consisting of Tris- $\mathrm{HCl} 10 \mathrm{mM} \mathrm{pH} 9.0$, $\mathrm{KCl} 50 \mathrm{mM}, \mathrm{MgCl}_{2} 2 \mathrm{mM}$, dNTP $0.2 \mathrm{mM}, 10$ pmoles of primer, $0.75 \mathrm{U}$ of Taq DNA polymerase (Pharmacia Biotech) and 10ng of genomic DNA. Reactions were performed in a Whatman Biometra (T Gradient) thermal cycler. The PCR program consisted of one step for $4 \mathrm{~min}$ at $94{ }^{\circ} \mathrm{C}, 45$ cycles of $1 \mathrm{~min}$ at $94{ }^{\circ} \mathrm{C}, 1 \mathrm{~min}$ at $36^{\circ} \mathrm{C}, 2 \mathrm{~min}$ at $72{ }^{\circ} \mathrm{C}$, followed by a final extension step of $5 \mathrm{~min}$ at $72{ }^{\circ} \mathrm{C}$ (ramp time from $36^{\circ} \mathrm{C}$ to $72{ }^{\circ} \mathrm{C}$ equal to $2 \mathrm{~min}$ ). All primers used were 10-base oligomers obtained from Operon Tech-

Table 1 - Locations, coordinates, and sample sizes of Aedes aegypti collections in Brazil.

\begin{tabular}{|c|c|c|c|}
\hline State & Cities & Latitude/Longitude & NR \\
\hline Ceará & Juazeiro do Norte (JUA) & $07^{\circ} 12^{\prime} 47^{\prime \prime} \mathrm{S} / 39^{\circ} 18^{\prime} 55^{\prime \prime} \mathrm{W}$ & 5 \\
\hline Alagoas & Maceió (MAC) & $09^{\circ} 39^{\prime} 57^{\prime \prime} \mathrm{S} / 35^{\circ} 44^{\prime} 07^{\prime \prime} \mathrm{W}$ & 10 \\
\hline Mato Grosso do Sul & Campo Grande (CGR) & $09^{\circ} 57^{\prime} 28^{\prime \prime} \mathrm{S} / 36^{\circ} 47^{\prime} 30^{\prime \prime} \mathrm{W}$ & 9 \\
\hline Rondônia & Vilhena (VIL) & $12^{\circ} 44^{\prime} 26^{\prime \prime} \mathrm{S} / 60^{\circ} 08^{\prime} 45^{\prime \prime} \mathrm{W}$ & 10 \\
\hline Rondônia & Porto Velho (PVE) & $15^{\circ} 38^{\prime} 42^{\prime \prime} \mathrm{S} / 56^{\circ} 05^{\prime} 52^{\prime \prime} \mathrm{W}$ & 20 \\
\hline Paraná & Londrina (LON) & $23^{\circ} 18^{\prime} 37^{\prime \prime} \mathrm{S} / 51^{\circ} 09^{\prime} 46^{\prime \prime} \mathrm{W}$ & 5 \\
\hline São Paulo & Barretos (BAR) & $20^{\circ} 33^{\prime} 26^{\prime \prime} \mathrm{S} / 48^{\circ} 34^{\prime} 04^{\prime \prime} \mathrm{W}$ & 10 \\
\hline São Paulo & Bauru (BAU) & $22^{\circ} 18^{\prime} 53^{\prime \prime} \mathrm{S} / 49^{\circ} 39^{\prime} 38^{\prime \prime} \mathrm{W}$ & 10 \\
\hline São Paulo & Botucatu (BOT) & $22^{\circ} 53^{\prime} 09^{\prime \prime} \mathrm{S} / 48^{\circ} 26^{\prime} 42^{\prime \prime} \mathrm{W}$ & 10 \\
\hline São Paulo & Campinas (CAM) & $28^{\circ} 57^{\prime} 39^{\prime \prime} \mathrm{S} / 51^{\circ} 31^{\prime} 55^{\prime \prime} \mathrm{W}$ & 10 \\
\hline São Paulo & Santos (SAN) & $23^{\circ} 57^{\prime} 39^{\prime \prime} \mathrm{S} / 46^{\circ} 20^{\prime} 01^{\prime \prime} \mathrm{W}$ & 5 \\
\hline Puerto Rico & Rockefeller (RCK) & $18^{\circ} 25^{\prime} 22^{\prime \prime} \mathrm{N} / 66^{\circ} 02^{\prime} 59^{\prime \prime} \mathrm{W}$ & 10 \\
\hline Total & & & 114 \\
\hline
\end{tabular}

$\mathrm{N}_{\mathrm{R}}$ the numbers of individuals from each population used for the RAPD analysis. 
nologies (Alameda, CA). Three oligonucleotides were described previously in the literature A02, B03, B13 (Ballinger-Crabtree et al., 1992). We screened eleven other primers (A10, B06, B10, B16, B20, K20, X16, W01, W03, $\mathrm{W} 10, \mathrm{~W} 16)$ and used two of them in the analyses. Oligonucleotide primers were selected on the basis of their reproducibility and presence of polymorphic products. Primers used in this analysis have the following sequences (5'-3'): A02, TGCCGAGCTG: B03, CATCCCCCTG: B13, TTCCCCCGCT: W01, CTCAGTGTCC: W03, GTCCGGAGTG. All amplification reactions were repeated twice in order to test reproducibility. The RAPD products were analyzed by electrophoresis in $1.5 \%(\mathrm{w} / \mathrm{v})$ agarose gels run for $1.5 \mathrm{~h}$ using $1 \mathrm{X}$ TAE buffer (Tris-acetate $40 \mathrm{mM} \mathrm{pH}$ 7.6, EDTA $1 \mathrm{mM}$ ). Gels were stained with ethidium bromide according to Sambrook et al. (1989) and photographed under ultraviolet light using a Nikon 750 camera. The sizes of DNA fragments were estimated by comparisons with the standard Ladder $250 \mathrm{bp}$ (Invitrogen).

Amplified fragments, named by the primer used and the molecular mass in base pairs (bp), were scored as the presence (1) or absence ( 0 ) of homologous bands, and a matrix of the different RAPD genotypes was assembled. The RAPD markers were analyzed as genetic markers under the following assumptions: (1) RAPD markers segregate in a Mendelian fashion; and (2) genotype frequencies at RAPD loci are in Hardy-Weinberg proportions (GorrochoteguiEscalante et al., 2000).

RAPDDIST in RAPDPLOT (Black, 1996) softwares were used to compute pairwise distances between samples and populations. We analyzed the data using all the genetic distance measures available in RAPDDIST with the Lynch and Milligan (1994) method correction factor for small sample sizes. $\mathrm{F}_{\mathrm{ST}}$ values between collections were compiled into a distance matrix. Genetic similarity was summarized in an unweighted pair-group method with an arithmetic average dendogram (UPGMA), for which bootstrap values based on 1,000 replicates were calculated (Felsenstein, 1985).

Comparing distance matrices between matrices of genetic and linear geographic distances tested the possibility of isolation by distance. Geographic coordinates were obtained with GPS and geographic distance matrices were made using GenALEx package (Peakall and Smouse, 2005) to compute the Mantel statistics (Mantel and Valand, 1970). Regression analysis and the Mantel test were performed using Mantel (Rousset, 1997). Resulting $r$-values were interpreted as correlation coefficients. Additionally, the frequencies were used to calculate mean heterozygosity. The population differentiation parameter $\mathrm{G}_{\mathrm{ST}}$ and unbiased genetic distances (Nei, 1978) were calculated among populations using POPGENE software (Yeh et al., 1997).

Amplifications of $A$. aegypti genomic DNA with 5 primers generated 21 reproducible and polymorphic mark- ers among natural Brazilian populations. Two markers were present only in the populations of Juazeiro do Norte and Alagoas. Beside these 21 markers, six others were exclusive to Rockefeller (laboratory strain). The number of bands per primer varied from two to six, ranging from 250 to 1500 base pairs.

The dendogram constructed using the UPGMA method (Figure 2) shows that the Rockefeller population represents a distinct group from the Brazilian populations in $100 \%$ of the 1000 bootstraps trees. A. aegypti Brazilian populations could be separated into two clusters, one group representing two populations from the Northeast (Maceió and Juazeiro do Norte), while the other group (Vilhena, Porto Velho, Campo Grande, Botucatu, Barretos, Bauru, Santos, Campinas and Londrina) consists of 10 populations from the Southeastern, Central and Northern regions. The second cluster was further divided into two smaller clusters that correspond to the geographical origin of the samples. Genetic distance between the two main clusters suggests that these populations are undergoing genetic differentiation, a process that may be driven by ecological, and evolutionary or historical factors.

The differentiation observed in the A. aegypti population from Botucatu (when compared to Bauru that is $80 \mathrm{~km}$ apart), probably resulted from repeated founder events followed by a reduction of genetic variability due to the city's characteristics. Botucatu is a relative small city, compared with others in this study, with a pronounced cold period. Captures performed in the cold period lead to very few eggs, and during the hot period Aedes albopictus is the major mosquito species (Nogueira et al., 2005).

Heterozygosities ranged from $0.209( \pm 0.019)$ in the $\mathrm{SE}$ (Southeast) to $0.211( \pm 0.028)$ in the NE (Northeast). In a similar manner, the total average gene diversity was unusually high $\left(\mathrm{H}_{\mathrm{T}}=0.388 \pm 0.009\right)$. The overall differentiation among the eleven analyzed wild Brazilian populations was high $\left(\mathrm{G}_{\mathrm{ST}}=0.430 ; \mathrm{Nm}=0.65\right)$. The intrastate $\mathrm{G}_{\mathrm{ST}}$ value

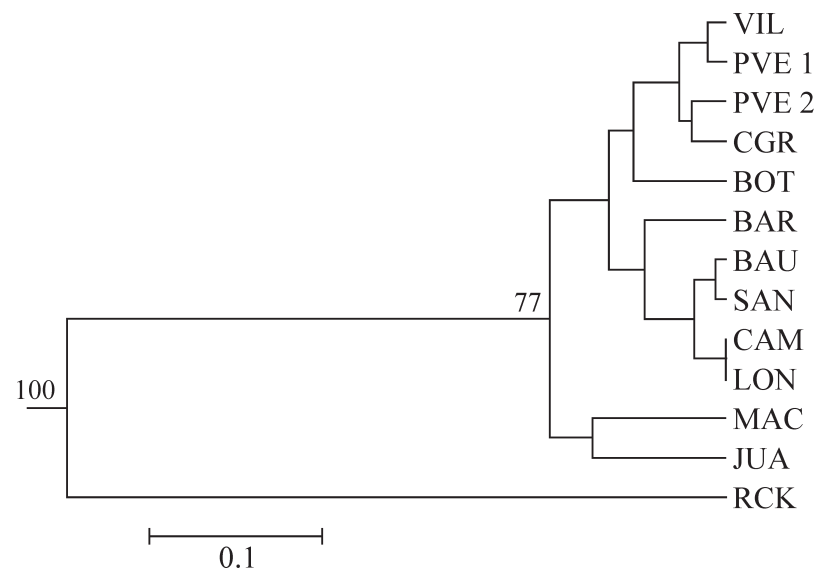

Figure 2 - Dendogram based on Nei's genetic distance (Nei 1978) among A. aegypti populations in Brazil. Bootstrap values over $50 \%$, based in 1,000 permutations are indicated on nodes. Analysis was done using the random amplified polymorphic DNA markers. 
varied from $0.374(\mathrm{Nm}=0.835)$ in Sao Paulo State $(\mathrm{BAU}$, BAR, BTU, CAM, SAN) to $0.208(\mathrm{Nm}=1.90)$ in the populations of Central and Northern regions (CGR, PVE, and VIL).

The RAPD method has been reported as an efficient tool to detect differentiation of geographically and genetically isolated populations (Ballinger-Crabtree et al., 1992; Apostol et al., 1994; Gorrochotegui-Escalante et al., 2000; Souza et al., 2001). The results presented in this study demonstrate a significant correlation between genetic and geographic distances of Brazilian Aedes populations. The data also showed the presence of two partially isolated groups, one representing mosquitoes from the Northeast and another one with populations from the North, Central and South of Brazil.

The average heterozygosity among the 21 RAPD loci $\left(\mathrm{H}_{\mathrm{T}}=0.388\right)$ was similar to that obtained in an analysis in Brazil using 27 RAPD loci $\left(\mathrm{H}_{\mathrm{T}}=0.390\right)$ (Ayres et al., 2003) and also to that obtained for 57 loci in Puerto Rico $\left(\mathrm{H}_{\mathrm{T}}=0.354\right)$ (Apostol et al., 1996). Genetic diversity among Brazilian A. aegypti populations was significant and shows that these populations are highly differentiated $\left(\mathrm{G}_{\mathrm{ST}}=0.430 ; \mathrm{Nm}=0.65\right)$ and very polymorphic $(\mathrm{Hs}=0.224)$. These values were similar to those described for other populations of this species in Brazil $\left(\mathrm{G}_{\mathrm{ST}}=0.317\right.$; $\mathrm{Nm}=0.54 ; \mathrm{H}_{\mathrm{S}}=0.274$ ) (Ayres et al., 2003) and Argentina $\left(\mathrm{G}_{\mathrm{ST}}=0.249 ; \mathrm{Nm}=0.75\right)($ Souza et al., 2001).

Analysis among populations of two geographic regions where commercial traffic is intense, mainly due soybean transportation by road, as seen in the North (PVE and VIL) and Central West (CGR), showed low population differentiation $\left(\mathrm{G}_{\mathrm{ST}}=0.208\right)$ with a higher degree of gene flow $(\mathrm{Nm}=1.90)$, indicating the importance of human activity to mosquito spread. Genetic distances also tended to be smaller between samples from northeastern Mexico (Gorrochotegui-Escalante et al., 2000), suggesting that in this locality $A$. aegypti dispersal occurs primarily through human commerce; whereas in the Yucatàn, genetic distances were larger, indicating that here A. aegypti dispersal may occur mainly through flight).

$\mathrm{F}_{\mathrm{ST}}$ values were estimated following Lynch and Milligan (1994). $\mathrm{F}_{\mathrm{ST}} /\left(1-\mathrm{F}_{\mathrm{ST}}\right)$ values were plotted against $\log _{10}$ (geographical distances $(\mathrm{km})$ ) estimated from GPS coordinates. This analysis indicated a significant correlation between genetic distances and the geographic distance $\left(\mathrm{r}^{2}=0.2089, \mathrm{p}<0.005\right)$ of A. aegypti in Brazil. A. aegypti populations from French Guiana are highly differentiated $\left(\mathrm{F}_{\mathrm{ST}}=0.111\right)$ even among seven sites that are less than $30 \mathrm{~km}$ apart $\left(\mathrm{F}_{\mathrm{ST}}=0.137\right)$, but show no positive correlation with geographic distance. Ravel et al. (2002) studied the genetic variation of $A$. aegypti in Côte d'Ivoire, by microssatellite and detected evidence for a microgeographic genetic differentiation of mosquitoes from Bouaké, with populations being genetically distinct along a north-south transect not related to geographic distances. In another study, Huber et al. (2002) detected a significant genetic structuring of the species in the city area of Ho Chi Minh, Vietnam.

Structured populations usually show a dynamic equilibrium between factors that favor differentiation (mutation, drift, and directional or disruptive natural selection, differing in each area) and homogenizing factors (migration, purifying natural selection, and balanced or differential natural selection, uniform in each area) (Solé-Cava, 2001). In our study, analyses of $A$. aegypti in Brazil suggest three geographically differentiated regions (the Northeast, the Southeast and the Central/North). The Northeastern differentiation may be due to a lack of migration between this region and the rest of the country. The Central and Northern differentiation could be result of the connections between cities through the main routes of commercial transit and not the consequence of active migration by mosquito populations. High diversity within and high similarities between groups of populations, as indicated by the RAPD markers, reflect the recent introduction of this species into Brazil, which involved a large number of individuals.

\section{Acknowledgments}

This work was funded by a grant from the Fundação de Amparo à Pesquisa do Estado de São Paulo (FAPESP Proc. No. 01/06647-9). KSP and PEMR are supported by scholarships from FAPESP and $\mathrm{CNPq}$, respectively. We thank Maria de Lourdes G. Macoris (from SUCEN) and Dr. Newton G. Madeira (from UNESP) for providing mosquito samples, and Newton G. Madeira for helpful comments and suggestions. We also thank Dr. Willian Black VI for providing the programs to analyze RAPD data.

\section{References}

Apostol BL, Black WC, Reiter P and Miller BR (1994) Use of randomly amplified polymorphic DNA polymerase chain reaction markers to estimate the number of Aedes aegypti families at oviposition sites in San Juan, Puerto Rico. Am J Trop Med Hyg 51:89-97.

Apostol BL, Black WC, Reiter P and Miller BR (1996) Population genetics with RAPD-PCR markers: The breeding structure of Aedes aegypti in Puerto Rico. Heredity 76:325-334.

Ayres CFJ, Melo-Santos MAV, Solé-Cava AM and Furtado AF (2003) Genetic differentiation of Aedes aegypti (Diptera, Culicidae), the major dengue vector in Brazil. J Med Entomol 40:430-435.

Ballinger-Crabtree ME, Black WC and Miller BR (1992) Use of genetic polymorphisms detected by the random amplified polymorphic DNA polymerase chain reaction (RAPD-PCR) for differentiation and identification of Aedes aegypti subspecies and populations. Am J Trop Med Hyg 47:893-901.

Bender W, Spierer P and Hogness DS (1983) Chromosomal walking and jumping to isolate DNA from the Ace and rosy loci and the bithorax complex in Drosophila melanogaster. J Mol Biol 168:17-33. 
Black WC (1996) RAPDPLOT 2.4 Department of Microbiology Colorado State University, Fort Collins, Colorado, USA.

Clark AG and Lanigan CMS (1993) Prospects for estimating nucleotide divergence with RAPDs. Mol Biol Evol 10:10961111.

Felsenstein J (1985) Confidence limits on phylogenies: An approach using the bootstrap. Evolution 39:783-791.

FUNASA 2003. http://www.funasa.gov.br.

Gorrochotegui-Escalante N, Munoz ML, Fernandez-Salas I, Beaty BJ and Black WC (2000) Genetic isolation by distance among Aedes aegypti populations along the northeastern coast of Mexico. Am J Trop Med Hyg 62:200-209.

Gubler DJ (2002) Epidemic dengue/dengue hemorrhagic fever as a public health, social and economic problem in the $21^{\text {st }}$ century. Trends Microbiol 2:100-103.

Gubler DJ (1998) Dengue. In: Monath TP (ed) The Arboviruses. Epidemiology and Ecology. CRC Press, Florida, pp 223260.

Huber K, Loan LL, Hoang TH, Tien TK, Rodhain F and Failloux AB (2002) Temporal genetic variation in Aedes aegypti populations in Ho Chi Minh City (Vietnam). Heredity 89:7-14.

Linch M and Milligan BG (1994) Analysis of populations genetic structure with RAPD markers. Mol Ecol 3:91-99.

Mantel N and Valand RS (1970) A technique of a nonparametric multivariate analysis. Biometrics 26:547-558.

Nei M (1978) Estimation of average heterozygosity and genetic distance from a small number of individuals. Genetics 89:583-590.

Nogueira LA, Gushi LT, Miranda JE, Madeira NG and Ribolla PEM (2005) Application of an alternative Aedes sp (Diptera, Culicidae) surveillance method in Botucatu city, São Paulo, Brazil. Am J Trop Med Hyg 73:309-311.
Peakall R and Smouse PE (2005) GenAlEx 6: Genetic Analysis in Excel. Population Genetic Software for Teaching and Research. The Australian National University, Canberra, Australia.

Rousset F (1997) Genetic differentiation and estimation of gene flow from F-statistics under isolation by distance. Genetics 145:1219-1228.

Ravel S, Hervé JP, Diarrassouba S, Kone A and Cuny G (2002) Microsatellite markers for population genetic studies in Aedes aegypti (Diptera, Culicidae) from Côte d'Ivoire: Evidence for a microgeographic genetic differentiation of mosquitoes from Bouaké. Acta Trop 1:39-49.

Sambrook J, Fritsch EF and Maniats T (1989) Molecular Cloning: A Laboratory Manual. 2nd edition. Cold Spring Harbor Laboratory, Cold Spring Harbor, NY.

Schatzmayr HG (2000) Dengue situation in Brazil by year 2000. Mem Inst Oswaldo Cruz 95:179-181.

Schleissman DJ and Calheiros LB (1974) A review of the status of yellow fever and Aedes aegypti eradication programs in the Americas. Mosq News 34:1-9.

Solé-Cava AM (2001) Biodiversidade molecular e genética da conservação. In: Matioli SR (ed) Biologia Molecular e Evolução. Holos, Ribeirão Preto, pp 172-192.

Souza GB, Blanco CA and Gardenal CN (2001) Genetic relationships among Aedes aegypti (Diptera, Culicidae) populations from Argentina using random amplified polymorphic DNA polymerase chain reactions markers. J Med Entomol 38:371-375.

Yeh FC and Boyle TJB (1997) Population genetic analysis of co-dominant and dominant markers and quantitative traits. Belg J Bot 129:157.

Editor: Fábio de Melo Sene 